\title{
Correction to: A Structured Literature Review and International Consensus Validation of FORTA Labels of Oral Anticoagulants for Long-Term Treatment of Atrial Fibrillation in Older Patients (OAC-FORTA 2019)
}

\author{
Farhad Pazan ${ }^{1} \cdot$ Ronan Collins ${ }^{2}$ - Victor M. Gil ${ }^{3}$. Olivier Hanon ${ }^{4} \cdot$ Roland Hardt $^{5} \cdot$ Martin Hoffmeister $^{6}$. \\ Pedro Monteiro ${ }^{7} \cdot$ Terence J. Quinn $^{8} \cdot$ Dieter Ropers $^{9} \cdot$ Giuseppe Sergi $^{10} \cdot$ Freek W. A. Verheugt $^{11} \cdot$ Martin Wehling $^{1}$
}

Published online: 14 June 2021

(c) The Author(s) 2021

\section{Correction to: Drugs \& Aging (2020) 37:539-548 https://doi.org/10.1007/s40266-020-00771-0}

The article A Structured Literature Review and International Consensus Validation of FORTA Labels of Oral Anticoagulants for Long-Term Treatment of Atrial Fibrillation in Older Patients (OAC-FORTA 2019), written by Farhad Pazan, Ronan Collins, Victor M. Gil, Olivier Hanon, Roland Hardt, Martin Hofmeister, Pedro Monteiro, Terence J. Quinn, Dieter Ropers, Giuseppe Sergi, Freek W. A. Verheugt, Martin Wehling was originally published Online First without open access. After publication in volume 37, issue 7, pages 539-548, the Authors requested that the article be Open Choice to make the article an open access publication on May 25th.

The original article can be found online at https://doi.org/10.1007/ s40266-020-00771-0.

Martin Wehling

martin.wehling@medma.uni-heidelberg.de

1 Clinical Pharmacology Mannheim, Faculty of Medicine Mannheim, University of Heidelberg, Theodor-Kutzer-Ufer 1-3, 68167 Mannheim, Germany

2 Stroke-Service/Age-Related Health Care, Tallaght Hospital, Dublin 24, Ireland

3 Cardiovascular Department, Hospital dos Lusíadas, Rua Abílio Mendes, 1500-458 Lisbon, Portugal

4 Service de Gérontologie, Hôpital Broca-Assistance Publique-Hôpitaux de Paris, Université Paris Descartes, Sorbonne Paris Cité, Equipe d'Accueil (EA) 4468, Paris, France

5 Department of Geriatrics, University Medical Center, University of Mainz, Langenbeckstr. 1, 55131 Mainz, Germany
This article is licensed under a Creative Commons Attribution-NonCommercial 4.0 International License, which permits any non-commercial use, sharing, adaptation, distribution and reproduction in any medium or format, as long as you give appropriate credit to the original author(s) and the source, provide a link to the Creative Commons licence, and indicate if changes were made. The images or other third party material in this article are included in the article's Creative Commons licence, unless indicated otherwise in a credit line to the material. If material is not included in the article's Creative Commons licence and your intended use is not permitted by statutory regulation or exceeds the permitted use, you will need to obtain permission directly from the copyright holder. To view a copy of this licence, visit http://creativecommons.org/licenses/by-nc/4.0/.

The original article has been corrected.

6 Cardiology, Städtisches Klinikum Solingen, Gotenstraße 1, 42653 Solingen, Germany

7 Cardiology Department, Coimbra University Hospital, Praceta Prof. Mota Pinto, 3000-075 Coimbra, Portugal

8 Institute of Cardiovascular and Medical Sciences, University of Glasgow, New Lister Building, Glasgow Royal Infirmary, Glasgow G4 0SF, UK

9 Department of Internal Medicine 1-Cardiology, St. Theresien-Krankenhaus Nuremberg, Mommsenstrasse 24, 90941 Nuremberg, Germany

10 Clinica Geriatrica-Ospedale Giustinianeo (2nd piano), University of Padova, via Giustiniani 2, 35128 Padua, Italy

11 P.C. Hooftstraat 188, $1071 \mathrm{CH}$ Amsterdam, The Netherlands 
Open Access This article is licensed under a Creative Commons Attribution-NonCommercial 4.0 International License, which permits any non-commercial use, sharing, adaptation, distribution and reproduction in any medium or format, as long as you give appropriate credit to the original author(s) and the source, provide a link to the Creative Commons licence, and indicate if changes were made. The images or other third party material in this article are included in the article's Creative Commons licence, unless indicated otherwise in a credit line to the material. If material is not included in the article's Creative Commons licence and your intended use is not permitted by statutory regulation or exceeds the permitted use, you will need to obtain permission directly from the copyright holder. To view a copy of this licence, visit http://creativecommons.org/licenses/by-nc/4.0/. 